\title{
Pollen morphology and its taxonomic significance in the genus Bomarea Mirb. (Alstroemeriaceae) - I. Subgenera Baccata, Sphaerine, and Wichuraea
}

\author{
Abul Khayer Mohammad Golam Sarwar ${ }^{1,2 *}$, Yoichiro Hoshino ${ }^{1}$ and Hajime Araki ${ }^{1}$
}

Received: April 7, 2015. Accepted: May 19, 2015

\begin{abstract}
Pollen morphology of 24 of the 33 species of three Bomarea subgenera, Baccata, Sphaerine, and Wichuraea, was examined by light microscopy (LM) and scanning electron microscopy (SEM), or SEM alone. The studied species of Bomarea were stenopalynous, characterized by large, monosulcate monads with reticulate exine sculpture in most species. Opercula-like structures were present on the sulcus in B. huanuco and B. involucrosa. Differences in pollen size, exine thickness, and exine sculpture were observed. The studied taxa were divided into four major groups based on exine ornamentation observed under SEM: microreticulate, reticulate, coarsely rugulate, or finely rugulate-perforate. Pollen characters alone did not appear to correlate clearly with the current subgeneric classification of Bomarea, but they may have some taxonomic utility below the subgeneric level. The most reliable infrageneric classification of Bomarea can be achieved through combined analyses of morphological, palynological, and molecular data from larger samples of specimens of all the species.
\end{abstract}

Keywords: Bomarea, exine sculpture, infrageneric classification, opercula-like structures, scanning electron microscopy

\section{Introduction}

Bomarea is the most diverse genus of Alstroemeriaceae, with 100-120 species (Neuendrof 1977; Alzate 2005) distributed primarily in the Andean and Austroamerican regions, but found from Mexico and the Caribbean to Chile and Argentina (Sanso \& Xifreda 1995). The genus includes climbing, erect, or prostrate herbs with persistent, often resupinate leaves and rhizomes, umbellate inflorescences, free perianth segments, six stamens, an inferior ovary, and elongate and anacolpate pollen (Alzate 2007). The characteristic large inflorescences of Bomarea represent an important food source for birds and insects in the Andean highlands (Sanso \& Xifreda 1995); the starchy storage roots of several species of Bomarea are also used as food (Bayer 1998).

The circumscription and taxonomic relationships between the two largest and closely related genera of the family Alstroemeriaceae, Alstroemeria and Bomarea, have also been controversial, as some species have been published under both generic names with different epithets (Sanso \& Xifreda 1995; Hofreiter \& Tillich 2002). Along with other characters, the differences in pollen grain wall structure and exine ornamentation (sculpture) are found to be valuable characteristics for distinguishing between Alstroemeria and Bomarea (Sanso \& Xifreda 2001; Sarwar et al. 2010), and the close relationship between these two genera has also been confirmed by molecular data (Aagesen \& Sanso 2003). Based on morphological features, the genus Bomarea is traditionally divided into three to four subgenera: Baccata (five spp.), Bomarea s.str. (c. 79 spp.), Sphaerine (12 spp.), and Wichuraea (18 spp.) (Hofreiter \& Tillich 2002). Recently, the subgeneric circumscriptions of Baccata (Hofreiter 2008), Sphaerine (Hofreiter 2006), and Wichuraea (Hofreiter \& Tillich 2003) have been revised. However, three clades within Bomarea have been identified by Alzate et al. (2008), using the genomic regions nrDNA ITS, $p s b A$-trn H, rpoB-trnC, and mat $K$, which conflicts with the traditional subgeneric classification of Bomarea based on morphology and biogeography.

Erdtman (1952, p. 44) described the pollen grains of Bomarea as "1-sulcate, large (longest axis 75-100 $\mu \mathrm{m}$ ), usually distinctly plane-convex with sulcus on the convex part of grains, sexine scrobiculoidate; sexine is thicker than nexine." Pollen morphology of Bomarea has also been included in some taxonomic papers and/or as a part of regional flora (Elsik \& Thanikaimoni 1970; Heusser 1971; Neuendorf

${ }^{1}$ Field Science Center for Northern Biosphere, Hokkaido University, Sapporo 060-0811, Japan

${ }^{2}$ Department of Crop Botany, Bangladesh Agricultural University, Mymensingh 2202, Bangladesh

* Corresponding author: drsarwar@bau.edu.bd 
1977; Schulze 1978; Kosenko 1994; Rudall et al. 2000; Rojas \& Gutiérrez 2001; Sanso \& Xifreda 2001; Hofreiter 2006; Alzate 2007). As a part of the comprehensive pollen morphological survey on the family Alstroemeriaceae, pollen morphology of the genus Alstroemeria has already been published (Sarwar et al. 2010). We present herein pollen morphological features of three subgenera, viz. Baccata, Sphaerine, and Wichuraea, of the genus Bomarea to search for new characters that could add information pertinent to infrageneric classification of this genus. The evolutionary trend in palynological features has also been discussed in light of the molecular phylogenetic relationships of Bomarea (Alzate et al. 2008).

\section{Materials and Methods}

Pollen morphology of a total of 24 species of three subgenera of the genus Bomarea, i.e., Baccata Hofreiter (three spp. out of five, Hofreiter 2008), Sphaerine (Herb.) Baker (nine spp. out of 12, Hofreiter 2006), and Wichuraea (M. Roemer) Baker (12 spp. out of 16, Hofreiter \& Tillich 2003), was examined by means of light microscopy (LM) and scanning electron microscopy (SEM), or SEM alone (Tab. 1). Polliniferous materials used in this investigation were taken from dried specimens from the herbaria $\mathrm{MO}$, USM, K, and MOL. Abbreviations of the herbarium names are according to the Index Herbariorum (Thiers 2007).

The preparation of pollen grains for LM and SEM, and pollen parameters studied follow Sarwar et al. (2010). Pollen slides of all collection are deposited at the Hokkaido University Museum, Sapporo, Japan. The measurements are based on at least 30 randomly selected grains from each specimen (Tab.2). Pollen size and shape classes were made following Erdtman (1952) and descriptive terminology follows Punt et al. (2007).

\section{Results}

The pollen grains of Bomarea species investigated were monad, large, ellipsoid (boat-shaped), heteropolar; monosulcate, sulcus on the convex part of the grains, distinct, long, straight, wide at the equator, narrow near the poles, sometimes extended to the proximal pole (Fig. 1A); auricula-like structures at the end of sulcus were observed in B. brachysepala, B. bracteolata, B. glaucescens, and B. huanuco (Fig. 1B; Tab. 2), opercula-like structures were present on the sulcus in B. huanuco and B. involucrosa (Fig. 2A-B). Symmetry was bilateral. Sizes ranged from $27.88-52.70 \mu \mathrm{m}$ (polar length $\mathrm{P}) \times 44.46-79.19 \mu \mathrm{m}$ (equatorial diameter $\mathrm{E}$ ), $\mathrm{P} / \mathrm{E}$ 0.51-0.68, oblate in shape, exine thickness 1.08-2.39 $\mu \mathrm{m}$ (Tab. 2).

Table 1. List of Bomarea taxa used in this study along with their voucher specimens.

\begin{tabular}{|c|c|c|}
\hline No. & Taxa & Voucher specimens \\
\hline & Bomarea subg. Baccata (5 spp.) & \\
\hline 1. & B. bracteolata Gereau & $\begin{array}{l}\text { Panama: Ridge of the Cadillera de Tute, above Escuela Alto de Piedra, 05.06.1982. S. Knapp \& R.L. Dressler } 5456 \\
\text { (MO3042031) (LM, SEM) }\end{array}$ \\
\hline 2. & B. carderi Mast. & Panama: Panamá, 27.01.1966. E.L. Tyson, J.D. Dwyer \& K.E. Blum 3311 (MO2011164) (LM, SEM) \\
\hline \multirow[t]{2}{*}{3} & B. diffracta Baker & Colombia: Chocó, 06.01.1979. A. Gentry \& E. Renteria A. 23717 (MO2717115) (LM, SEM) \\
\hline & Bomarea subg. Sphaerine (12 spp.) & \\
\hline 4. & B. brachysepala Benth. & $\begin{array}{l}\text { Peru: Depto. Piura, Prov. Huancabamba. 07.27.2006. A. Cano, W. Mendoza \& N. Valencia } 16761 \text { (USM212472) } \\
\text { (LM, SEM) }\end{array}$ \\
\hline 5. & B. brevis (Herb.) Baker & Bolivia: La Paz, Sud Yungas, 07.11. 1982. J.C. Solmom 8745 (MO3148123) (SEM) \\
\hline 6. & B. coccinea (R. \& P.) Baker & Peru: Depto. Junin, Prov. Tarma. 13.01.1987. S.C. Dias \& S. Baldeon 2217 (USM163830) (SEM) \\
\hline 7. & B. distichifolia (R. \& P.) Baker & Peru: Dep. De Cajamarca, Prov. Jaen. Colasay, 7.3 - 9.5.1998. No name (USM202018) (LM, SEM) \\
\hline 8. & B. foertheriana Hofreiter & $\begin{array}{l}\text { Peru: Depto. De Pasco, Prov. Oxapampa. 21.11.2002. A. Monteagudo, C. Mateo \& G. Ortiz } 4360 \text { (USM198515) } \\
\text { (LM, SEM) }\end{array}$ \\
\hline 9. & B. huanuco Hofreiter & Peru: Huanuco, 15.01.1987. C. Diaz S. \& S. Baldeon 2249 (MO3518930) (LM, SEM) \\
\hline 10. & B. linifolia (H.B.K.) Baker & Colombia: Cauca Paramo de las Barbillas, near Guachicono 19.07.1944. E.L. Core 973 (MO1801230) (LM, SEM) \\
\hline 11. & B. nervosa (Herb.) Baker & $\begin{array}{l}\text { Peru: San Martín, 12.04.1984. T.B. Croat 58201A (MO3186188) (LM); Amazonas, Chachapoyas. 09.07.1962. J.J. } \\
\text { Wurdack } 1270 \text { (USM161711) (SEM) }\end{array}$ \\
\hline \multirow[t]{2}{*}{12} & B. pauciflora (H.B.K.) Herb. & Colombia: Cundinamarca, no day.08 - 12.1990. A. Repizzo \& Z. Calle 264 (MO4330152) (LM, SEM) \\
\hline & Bomarea subg. Wichuraea (16 spp.) & \\
\hline 13. & B. albimontana Smith \& Gereau & Peru: Ancash, Huaraz, 13.07.1985. D.N. Smith \& M. Buddensiek 11148 (MO3312498) (LM, SEM) \\
\hline 14. & B. ampayesana Vargas & Peru: Cusco, La Convención, 25.07.1944. C. Vargas C. 4439 (MO1633770) (LM, SEM) \\
\hline 15. & B. andimarcana (Herb.) Baker & Bolivia: La Paz Inquisiri, 19.12.1999. J.R.I. Wood and D.J. Goyder 15546 (K) (LM) \\
\hline 16. & B. chimboracensis Baker & Ecuador: Azuray, 15.8.1996. G.P. Lewis 2484 (K) (LM) \\
\hline
\end{tabular}


Table 1. Continuation.

\begin{tabular}{|c|c|c|}
\hline No. & Taxa & Voucher specimens \\
\hline 17. & B. dulcis (Hook.) Beauvard & Peru: Ancash, Cordillera blanca encima de Yungay, no date, A. Weberbauer 3268 (MOL00007284) (LM, SEM) \\
\hline 18. & B. glaucescens (H.B.K.) Baker & $\begin{array}{l}\text { Peru: Depto. San Martin, Prov. Mariscal Caseres. 25.06.96. A. Cano, K. Young, B. Leon \& J. Roque } 7307 \\
\text { (USM167984) (LM, SEM) }\end{array}$ \\
\hline 19. & B. involucrosa (Herb.) Baker & Peru: Lima, Huarochiri, 21.09.1982. D.N. Smith \& J. Alban C. 2357 (MO4398129) (LM, SEM) \\
\hline 20. & B. longistyla Vargas & Peru: Lima, Canta, 16.05.1992. G. Vilcapoma 1730 (MO4395443) (LM, SEM) \\
\hline 21. & B. parvifolia Baker & $\begin{array}{l}\text { Peru: Huaraz, Anacash, Yungay, 31.9.1975. S.G. Baunders } 1335 \text { (K) (LM); Ancash, Yungay, 28.01.1985. B.A. Stein } \\
2019 \text { (MO3294289) (SEM) }\end{array}$ \\
\hline 22. & B. porrecta Killip & Peru: Depto. La Libertad, Prov. Sanchez Carrion, Senal Huayllides. 21.08.1982. D. Smith 2267 (USM154048) (LM) \\
\hline 23. & B. torta (H.B.K.) Herb. & $\begin{array}{l}\text { Ecuador: Loza, 15.8.1996. G.P. Lewis } 2473 \text { (K) (LM); } \\
\text { Peru: Depto. Cajamarca, El Pargo. 18.09.1991. Al. Gentry, C. Diaz \& R. Ortiz } 74904 \text { (USM133439) (SEM) }\end{array}$ \\
\hline 24. & B. vargasii Hofreiter & Peru: Cumbemayo, Hill west and S of Cumbemayo, 5.2-2.4.97. M. Weigend, Dostert \& K. Drieble (USM971343) (SEM) \\
\hline
\end{tabular}

Table 2. Variation in pollen characters of Bomarea showing mean value in micrometer and standard deviation. Maximum - minimum values in micrometer in parenthesis; Taxa are arranged alphabetically within the group. (A) Pollen grains with auricula-like structure; n.d. Not discern.

\begin{tabular}{|c|c|c|c|c|c|c|}
\hline Name of Taxa & Polar length $(\mathrm{P})$ & Equatorial diameter (E) & $\mathrm{P} / \mathrm{E}$ & Exine thickness & Exine sculpture ${ }^{*}$ & Fig. No. \\
\hline \multicolumn{7}{|l|}{ Subg. Baccata } \\
\hline B. bracteolata (A) & $37.29 \pm 2.94(42.04-31.30)$ & $62.37 \pm 4.18(69.30-51.60)$ & 0.60 & $1.87 \pm 0.23(2.85-1.57)$ & Type III & $3 \mathrm{~K}$ \\
\hline B. carderi & $37.91 \pm 2.78(42.47-33.42)$ & $63.93 \pm 2.64(69.55-59.77)$ & 0.59 & $1.80 \pm 0.12(1.96-1.53)$ & Type I & $2 \mathrm{E}$ \\
\hline B. diffracta & $34.74 \pm 1.87(37.54-30.44)$ & $59.96 \pm 2.48(65.27-56.44)$ & 0.58 & 1.76 & Type II & $2 J$ \\
\hline \multicolumn{7}{|l|}{$\begin{array}{l}\text { Subg. Sphaerine } \\
\text { Distichifolia-group }\end{array}$} \\
\hline B. brevis & n.d. & n.d. & n.d. & n.d. & Type II & $2 \mathrm{~K}$ \\
\hline B. distichifolia & $30.13 \pm 2.97(34.30-24.76)$ & $44.46 \pm 4.16(52.83-39.23)$ & 0.68 & $1.52 \pm 0.08(1.70-1.43)$ & Type IV & $3 \mathrm{~L}$ \\
\hline B. foertheriana & $39.84 \pm 3.05(45.95-35.32)$ & $69.39 \pm 3.11(78.71-64.51)$ & 0.57 & $1.63 \pm 0.11(1.90-1.50)$ & Type II & $2 \mathrm{~L}$ \\
\hline B. huanuco (A) & $30.30 \pm 1.99(36.92-26.54)$ & $52.67 \pm 2.87(59.00-46.63)$ & 0.51 & $1.67 \pm 0.11(1.90-1.50)$ & Type II & $3 \mathrm{~A}$ \\
\hline B. nervosa & $35.30 \pm 3.79(42.06-29.41)$ & $53.88 \pm 1.46(56.39-50.47)$ & 0.66 & $1.66 \pm 0.13(1.90-1.53)$ & Type IV & $3 \mathrm{M}-\mathrm{N}$ \\
\hline \multicolumn{7}{|l|}{ Linifolia-group } \\
\hline B. brachysepala (A) & $33.04 \pm 2.50(38.90-29.30)$ & $56.60 \pm 2.53(61.23-51.68)$ & 0.58 & $1.67 \pm 0.11(1.9-1.5)$ & Type I & $2 \mathrm{~F}$ \\
\hline B. coccinea & n.d. & n.d. & n.d. & n.d. & Type I & $2 \mathrm{G}$ \\
\hline B. linifolia & $34.34 \pm 2.61(38.58-29.89)$ & $56.71 \pm 4.86(63.82-47.38)$ & 0.61 & $1.61 \pm 0.10(1.80-1.43)$ & Type III & 30 \\
\hline \multicolumn{7}{|l|}{ Pauciflora-group } \\
\hline B. pauciflora & $34.15 \pm 2.04(38.95-30.97)$ & $59.60 \pm 3.43(66.44-53.86)$ & 0.57 & $1.67 \pm 0.10(1.80-1.53)$ & Type I & $2 \mathrm{H}$ \\
\hline \multicolumn{7}{|l|}{$\begin{array}{l}\text { Subg.Wichuraea } \\
\text { Northern-group }\end{array}$} \\
\hline B. albimontana & $32.51 \pm 2.80(39.40-27.26)$ & $56.34 \pm 3.14(62.57-49.88)$ & 0.58 & $1.65 \pm 0.11(1.85-1.50)$ & Type II & $3 \mathrm{~B}$ \\
\hline B. chimboracensis & $30.12 \pm 4.91(42.16-24.67)$ & $53.66 \pm 5.34(64.25-46.03)$ & 0.56 & $2.32 \pm 0.22(2.72-1.90)$ & Type I & - \\
\hline B. glaucescens (A) & $31.61 \pm 2.15(35.86-27.89)$ & $58.26 \pm 2.84(64.64-51.41)$ & 0.58 & $1.56 \pm 0.10(1.80-1.35)$ & Type II & $3 \mathrm{C}$ \\
\hline B. porrecta & $33.45 \pm 1.68(36.97-31.10)$ & $59.80 \pm 2.72(63.40-54.52)$ & 0.56 & $1.31 \pm 0.07(1.50-1.20)$ & Type I & - \\
\hline B. vargasii & n.d. & n.d. & n.d. & n.d. & Type II & $3 \mathrm{D}$ \\
\hline B. torta & $30.46 \pm 3.50(40.11-25.33)$ & $55.40 \pm 4.33(65.12-45.73)$ & 0.60 & $2.39 \pm 0.24(2.85-1.75)$ & Type I & $2 \mathrm{I}$ \\
\hline \multicolumn{7}{|l|}{ Southern-group } \\
\hline B. ampayesana & $52.70 \pm 4.36(52.70-34.09)$ & $79.19 \pm 3.84(86.60-73.62)$ & 0.67 & $1.80 \pm 0.10(2.00-1.55)$ & Type II & $3 \mathrm{E}$ \\
\hline B. andimarcana & $39.85 \pm 3.95(53.10-33.27)$ & $65.89 \pm 4.59(78.33-54.53)$ & 0.60 & $2.31 \pm 0.27(2.72-1.80)$ & Type II & $3 \mathrm{~F}$ \\
\hline B. dulcis & $30.99 \pm 2.25(35.81-27.38)$ & $55.48 \pm 3.43(66.20-49.80)$ & 0.56 & $1.08 \pm 0.13(1.35-0.85)$ & Type II & $3 \mathrm{G}$ \\
\hline B. involucrosa & $36.49 \pm 2.13(41.82-33.97)$ & $68.40 \pm 2.55(72.30-62.45)$ & 0.56 & $1.60 \pm 0.10(1.75-1.43)$ & Type II & $3 \mathrm{H}$ \\
\hline B. longistyla & $40.39 \pm 2.37(44.68-34.63)$ & $68.90 \pm 2.48(75.32-64.20)$ & 0.59 & $1.45 \pm 0.11(1.75-1.20)$ & Type II & $3 \mathrm{I}$ \\
\hline B. parvifolia & $27.88 \pm 2.76(32.81-20.49)$ & $52.50 \pm 3.36(63.42-47.23)$ & 0.53 & $1.83 \pm 0.31(2.57-1.27)$ & Type II & $3 \mathrm{~J}$ \\
\hline
\end{tabular}

* Exine ornamentation type by SEM. Type I, microreticulate, lumina less than or equal $1 \mu \mathrm{m}$ in size; Type II, reticulate, lumina larger than $1 \mu \mathrm{m}$ in size; Type III, coarsely rugulate; Type IV, finely rugulate-perforate. For details see text. 

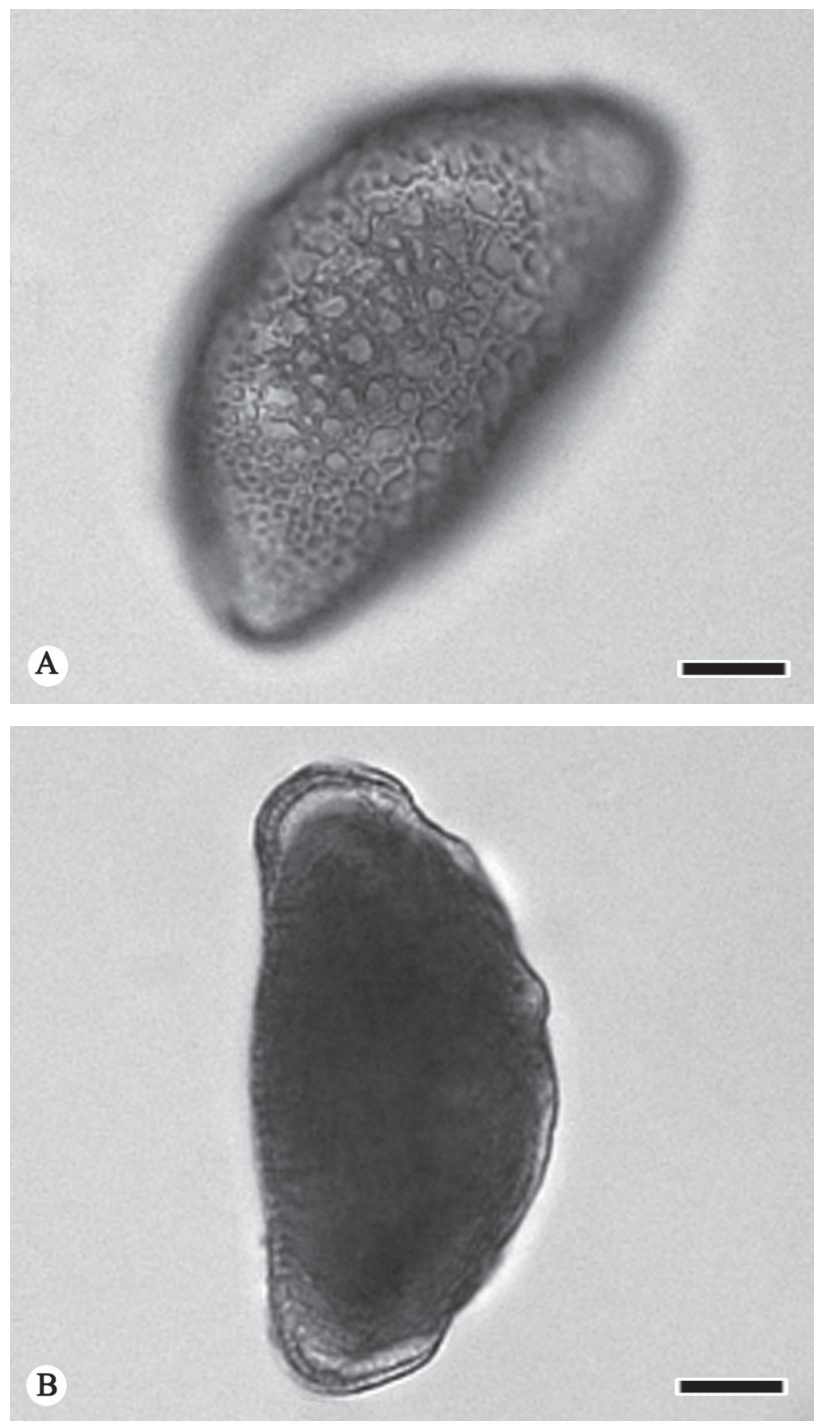

Figure 1. Light micrographs of Bomarea pollen grains (A-B). A. B. involucrosa (Smith \& Alban 2357); B. B. bracteolata (Knapp \& Dressler 5456). Scale bars: $10 \mu \mathrm{m}$.

The pollen grains of Bomarea species were characterized by a semitectate exine sculpture. Four different exine sculptures were observed among the species of Bomarea studied. Type I - Microreticulate (Fig. 2E-I; Tab. 2), with perforate muri, heterobrochate; lumina are less than or equal 1 $\mu \mathrm{m}$ in length or diameter, observed in B. brachysepala, B. carderi, B. coccinea, B. pauciflora, and B. torta.

Type II - Reticulate (Figs. 2J-L, 3A-J; Tab. 2), with perforate muri, heterobrochate; lumina are larger than 1 $\mu \mathrm{m}$ in length or diameter, observed in B. albimontana, B. ampayesana, B. andimarcana, B. brevis, B. diffracta, B. dulcis, B. foertheriana, B. glaucescens, B. huanuco, B. involucrosa, B. longistyla, B. parvifolia and B. vargasii. Type III - Coarsely rugulate (Fig. 3K, O; Tab. 2), observed in B. bracteolata and B. linifolia.

Type IV - Finely rugulate-perforate (Fig. 3L-N; Tab. 2), observed in B. distichifolia and B. nervosa.
Sometimes granula were visible at the bottom of the lumina; these correspond to reduced or modified columellae (Fig. 2J). The exine sculpture along with sulci was similar to that appearing at the equatorial position, but had relatively smaller lumina.

\section{Discussion}

\section{Variations in pollen morphology}

Most of the Bomarea species examined were characterized by monad, monosulcate, and large pollen indicating that the species of genus Bomarea are closely related (Figs. 1-3; Tab. 2). Thus far, the pollen morphology of only five species, viz. B. distichifolia, B. dulcis, B. glaucescens, B. involucrosa, and B. linifolia, of three subgenera has been studied with either LM or SEM. The results of present study are in agreement with previous reports (Erdtman 1952; Heusser 1971; Neuendorf 1977; Schulze 1978; Kosenko 1994; Sanso \& Xifreda 2001; Alzate 2007), and monophyly of the genus Bomarea is also supported by molecular data (Aagesen \& Sanso 2003; Alzate et al. 2008). However, there are significant differences in the value of quantitative palynological characters that may, to some extent, be related to differences in the preparation methods of pollen grains as well as the mounting media. Similar phenomena have also been observed and discussed for Alstroemeria (Sarwar et al. 2010 for detail). The pollen length (equatorial diameter) of studied Bomarea species varies from 44.46-79.19 $\mu \mathrm{m}$ (Tab. 2). This wide variation in pollen size might be correlated with floral size (Sarwar et al. 2010). Bomarea ampayesana produces the largest pollen (Tab. 2) and produces large showy flowers $10-12 \mathrm{~cm}$ in size (Hofreiter \& Tillich 2003).

Previously, the presence of possible opercula was only observed in the SEM illustration of B. salsilla (Kosenko 1994). Here, we have reported opercula-like structures present on the sulcus in two Bomarea spp., B. huanuco, and B. involucrosa (Fig. 2A-B). Although operculate pollen is fairly common in some families of the order Liliales, the presence of operculate pollen in these three Bomarea species as well as in Alstroemeriaceae requires confirmation (Furness \& Rudall 2003). However, it has been shown that insulae are present in the sulcus of some Alstroemeria pollen (Furness \& Rudall 2003; AKM Golam Sarwar unpubl. res.).

Among the studied species of these three subgenera, auricula-like structures in pollen grains were observed only in B. brachysepala, B. bracteolata, B. glaucescens, and B. huanuco (Fig. 1B; Tab. 2). Pollen with auricula-like structures has previously been reported for only two species of Bomarea (subgenus Bomarea), B. pardina (B. lyncina), and B. ceratophora (Elsik \& Thanikaimoni 1970; Neuendorf 1977; Schulze 1978). Elsik \& Thanikaimoni (1970) considered auriculae as equatorial modifications of the exine, and auriculae sometimes get detached from the pollen effectively creating a circular opening that resembles a pore. However, 
the auricula-like structures are absent in most of the species studied (Tab. 2; Elsik \& Thanikaimoni 1970; Sanso \& Xifreda 2001; AKM Golam Sarwar unpubl. res.).

Although pollen grains of Bomarea species are characterized by the (micro)reticulate exine sculptures (Type I, II; Figs. 2E-L, 3A-J), this study is the first to report the coarsely rugulate (Type III) and finely rugulate-perforate (Type IV) exine sculptures in Bomarea (Fig. 3K-O). The reticulate exine sculpture might be a plesiomorphic character state for Bomarea and the coarsely rugulate and the finely rugulate-perforate exine sculptures might have evolved independently more than once (Alzate et al. 2008).
The coarsely rugulate(-psilate) exine sculpture, observed both in Bomarea and Alstroemeria (Sarwar et al. 2010), might make a morphological (connection) bridge between striate-reticulate and reticulate exine sculptures. The major evolutionary trend of exine sculpture is postulated to be from reticulate through rugulate to striate-reticulate or vice-versa, in Alstroemeriaceae (Aagesen \& Sanso 2003). Alternately, the rugulate (or a different) pollen sculpturing could be plesiomorphic within the family and then both striate-reticulate and reticulate pollen sculpturing would be synapomorphies for Alstroemeria and Bomarea, respectively. With TEM thin-sections, it has been shown that the infra-
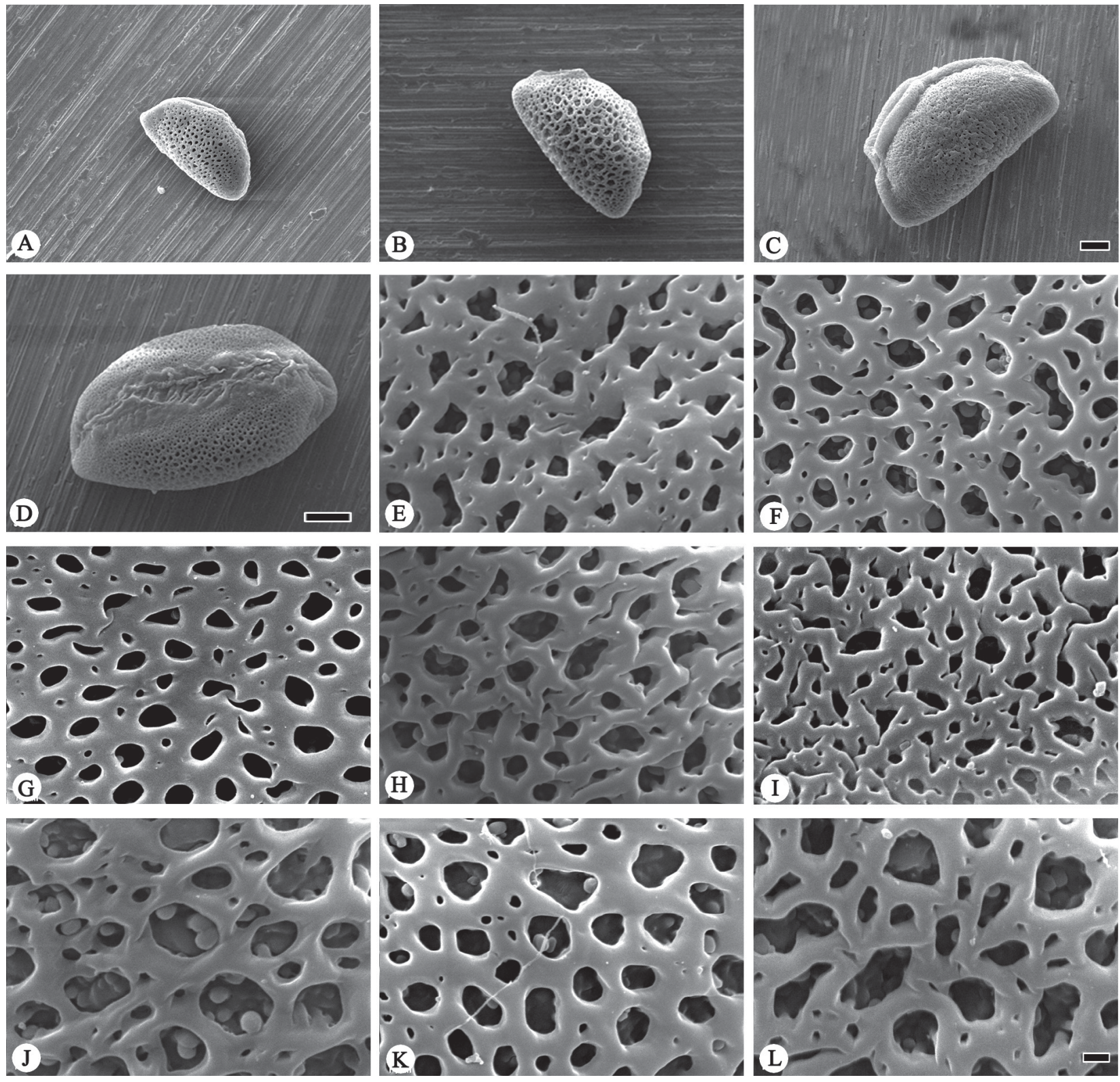

Figure 2. Scanning electron micrographs of Bomarea pollen. Pollen grain (A-D); exine sculpture (E-L). A. B. huanuco (Diaz \& Baldeon 2249); B. B. involucrosa (Smith \& Alban 2357); C. B. linifolia (Core 973); D. B. longistyla (Vilcapoma 1730); E. B. carderi (Tyson et al. 3311); F. B. brachysepala (Cano et al. 16761); G. B. coccinea (Camilo \& Baldeon 2217); H. B. pauciflora (Repizzo \& Calle 264); I. B. torta (Gentry et al. 74904); J. B. diffracta (Gentry \& Renteria 23717); K. B. brevis (Solmom 8745); L. B. foertheriana (Monteagudo et al. 4360). Scale bars A-D: $10 \mu \mathrm{m}, \mathrm{E}-\mathrm{L}: 1 \mu \mathrm{m}$. 

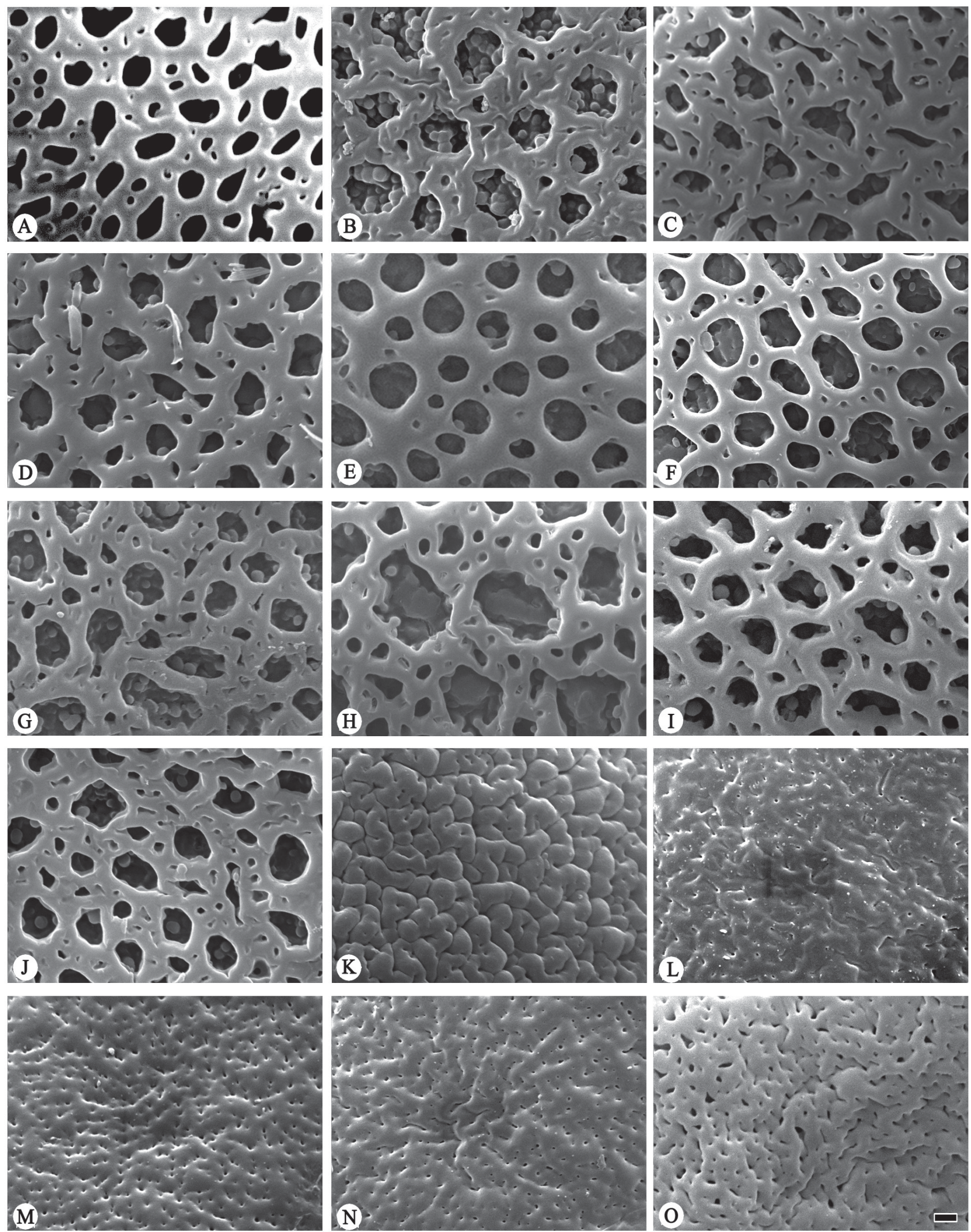

Figure 3. Scanning electron micrographs of Bomarea pollen. Exine sculpture (A-O). A. B. huanuco (Diaz \& Baldeon 2249); B. B. albimontana (Smith \& Buddensiek 11148); C. B. glaucescens (Cano et al. 7307); D. B. vargasii (Rodriguez \& Arroyo 2932); E. B. ampayesana (Vargas 4439); F. B. andimarcana (Wood and Goyder 15546); G. B. dulcis (Weberbauer 3268); H. B. involucrosa (Smith \& Alban 2357); I. B. longistyla (Vilcapoma 1730); J. B. parvifolia (Stein 2019); K. B. bracteolata (Knapp \& Dressler 5456); L. B. distichifolia (USM 202018); M-N. B. nervosa (Wurdack 1270); O. B. linifolia (Core 973). Scale bars: $1 \mu \mathrm{m}$. 
tectum corresponding with a reticulate exine in Bomarea has more widely spaced columellae (Fig. 5G in Sanso \& Xifreda 2001). We used the lumina diameter as a character of taxonomic importance; however, the arrangement (and thickness) of muri are sometimes found to be useful characters at the subgeneric level (Sanso \& Xifreda 2001).

The existence of a general relationship between pollen morphology and pollen vectors was suggested by Woodhouse (1935). The (micro)reticulate exine sculpture might represent a hummingbird mode of pollination in Bomarea, as all species of subgenus Wichuraea, including those with green flowers, are likely to be hummingbird pollinated (Hofreiter \& Tillich 2003). In contrast, coarsely rugulate and finely rugulate-perforate exine sculptures might be related to pollination by butterflies (Hofreiter 2006).

\section{Taxonomic significance of palynological features}

According to our results, pollen characters alone fail to distinguish between any subgenera of Bomarea (Hofreiter \& Tillich 2002), although pollen size (equatorial diameter) shows some variation among the subgenera Baccata $(59.96-63.93 \mu \mathrm{m})$, Sphaerine $(44.46-59.60 \mu \mathrm{m})$ except B. foertheriana, and Wichuraea $(55.50-79.19 \mu \mathrm{m})$ except B. parvifolia (Tab. 2). In an agglomerative hierarchical clustering (analysis) of Bomarea using quantitative pollen data, the studied species are distributed in either two (similarity based) or four (dissimilarity based) major clusters (AKM Golam Sarwar unpubl. res.). The recent molecular phylogenetic analyses of Bomarea (Alzate et al. 2008) have also failed to recover clades that represent traditionally recognized subgeneric taxa for the genus (Hofreiter \& Tillich 2002), but recovered three major clades. Only five of the studied species were included in this molecular study and these are positioned in two different clades (Fig. 2 in Alzate et al. 2008): Bomarea glaucescens is sister to the B. cumbrensis-B. diffracta subclade in clade A; B. linifolia is sister to the Leontochir ovallei (as B. ovallei)-B. involucrosa subclade in clade B; B. pauciflora is resolved as sister to clades $B$ and $C$ (Alzate et al. 2008). The sister relationship between B. glaucescens and B. diffracta is likely supported by pollen morphological features, but the relationship between B. linifolia and B. involucrosa is not (Tab. 2). However, pollen morphology may have some taxonomic utility below the subgeneric level.

The species of subgenus Sphaerine were arranged in three informal groups, viz. Distichifolia-, Linifolia-, and Pauciflora-groups (Hofreiter 2006). Palynological features may give additional support to this supposition. The pollen grains of the Distichifolia-group are comparatively smaller in size $(44.46-53.88 \mu \mathrm{m})$ except B. foertheriana $(69.39 \mu \mathrm{m})$, followed by the Linifolia-group $(56.60-56.71 \mu \mathrm{m})$, and the monospecific Pauciflora-group (59.60 $\mu \mathrm{m}$; Tab. 2). The exceptionally large pollen of $B$. foertheriana might be an adaptation to its specific habitat as it only occurs in the shadows of continually cool (without frost at night), wet, humid mist forests in Peru at $1300-3500 \mathrm{~m}$; it also produces much wider leaves compared with its thickness (Hofreiter \& Lyshede 2006).

Based on the geographical distribution, the species of subgenus Wichuraea were arranged in two groups: northern and southern (Hofreiter \& Tillich 2003). Morphologically, the species of the northern group are characterized by unguiculate inner tepals, i.e., these are divided into blade and claw. One-third to one-half of the ripe fruit originates from the part above the insertion level of the petals and stamens. The species of the southern group are characterized by their spatulate inner tepals. The gynoecium is semi-inferior, onehalf to two-thirds of the ripe fruit originate from the part above the insertion level of the tepals and stamina (Hofreiter \& Tillich 2003). This pattern is also supported by palynological characteristics. The pollen grains of the northern group are comparatively smaller in size $(53.66-59.80 \mu \mathrm{m})$ than those of the southern group $(65.89-78.94 \mu \mathrm{m})$ except B. parvifolia $(52.50 \mu \mathrm{m})$ and B. dulcis $(55.48 \mu \mathrm{m}$; Tab. 2). The flowers of the northern group are $2-3 \mathrm{~cm}$ long, i.e., they are also small compared to the flowers of some species of the southern group (Hofreiter \& Tillich 2003). The smaller pollen of B. parvifolia and B. dulcis are an indication of their limited distribution to a drier region and/or small flowers, and suggests similarities in other (external) morphological characters (Hofreiter \& Tillich 2003). In the southern group, $B$. parvifolia is restricted to the dry western cordilleras, whereas the widespread $B$. dulcis exclusively occurs above the fog forest region. Bomarea parvifolia grows in central Peru at altitudes between $3500 \mathrm{~m}$ and $4300 \mathrm{~m}$, almost exclusively on steep slopes and between rocks. Bomarea dulcis can occur up to $5200 \mathrm{~m}$, and has small leaves closely appressed to the stem (Hofreiter \& Tillich 2003). Pollen grains of members of the southern group are consistently characterized by Type II exine sculpture (Fig. 3E-J; Tab. 2).

According to Fishbein et al. (2001), morphology can be very useful in resolving the relationships within and among groups with rapid radiation events. Often minimal genetic changes are required to produce morphological variation, and these changes can be easily observed and quantified for use in phylogenetic inferences. Although pollen characters alone do not appear to correlate clearly with the current subgeneric classification of Bomarea (Hofreiter \& Tillich 2002), it would be useful to develop a morphological and anatomical data set for future systematic analyses of Bomarea (Hofreiter \& Lyshede 2006). The infrageneric classification of Bomarea can be reliably achieved by combined analyses of morphological, palynological, and molecular data from larger numbers of specimens of all species.

\section{Acknowledgements}

We thank the directors and curators of the consulted herbaria for allowing us to examine and/or for sending specimens on loan to sample polliniferous material. We 
appreciate the help of two anonymous reviewers for their valuable comments in improving this manuscript. The first author is especially grateful to the Japan Society for the Promotion of Science (JSPS) for the Postdoctoral Fellowship for Foreign Researchers during the period of this study.

\section{References}

Aagesen L, Sanso M. 2003. The phylogeny of the Alstroemeriaceae based on morphology, rps 16 intron and $r b c L$ sequence data. Systematic Botany 28: 47-69.

Alzate F. 2005. Three new species of Bomarea (Alstroemeriaceae) from the Andean region of Colombia. Novon 15: 253-258.

Alzate F. 2007. Two new species of Bomarea (Alstroemeriaceae) from Colombia. Novon 17: 141-144.

Alzate F, Mort ME, Ramirez M. 2008. Phylogenetic analyses of Bomarea (Alstroemeriaceae) based on combined analyses of nrDNA ITS, $p s b A$ $\operatorname{trnH}, r p o B-\operatorname{trn} C$ and $m a t K$ sequences. Taxon 57: 853-862.

Bayer E. 1998. Alstroemeriaceae. In: Kubitzki K. (ed.) Families and genera of vascular plants 3. Flowering plants. Monocotyledons: Lilianae (except Orchidaceae). Berlin, Springer-Verlag. p. 79-82.

Elsik WC, Thanikaimoni G. 1970. Bomarea lyncina Herb. (Amaryllidaceae) and Auriculiidites Elsik. Pollen et Spores 12: 177-180.

Erdtman G. 1952. Pollen morphology and plant taxonomy - Angiosperms. Leiden, E. J. Brill.

Fishbein M, Hibsch-Jetter C, Soltis DE, Hufford L. 2001. Phylogeny of Saxifragales (Angiosperms, Eudicots): analysis of a rapid, ancient radiation. Systematic Biology 50: 817-847.

Furness CA, Rudall PJ. 2003. Apertures with lids: Distribution and significance of operculate pollen in monocotyledons. International Journal of Plant Science 164: 835-854.

Heusser CJ. 1971. Pollen and spores of Chile. Tucson, Univ. Arizona Press.

Hofreiter A. 2006. Revision of Bomarea Mirb. Subgenus Sphaerine (Herb.) Baker (Alstroemeriaceae). Nordic Journal of Botany 24: 117-141.

Hofreiter A. 2008. Revision of Bomarea Mirb. Subgenus Baccata Hofr. (Alstroemeriaceae). Feddes Repertorium 119: 1-12.
Hofreiter A, Lyshede O. 2006. Functional leaf anatomy of Bomarea Mirb. (Alstroemeriaceae). Botanical Journal of the Linnean Society 152: 73-90.

Hofreiter A, Tillich HJ. 2002. The delimitation, ecology, distribution and infrageneric subdivision of Bomarea Mirbel (Alstroemeriaceae). Feddes Repertorium 113: 528-544.

Hofreiter A, Tillich HJ. 2003. Revision of the subgenus Wichuraea (M. Roemer) Baker of Bomarea Mirbel (Alstroemeriaceae). Feddes Repertorium 114: 208-239.

Kosenko VN. 1994. Pollen morphology of the family Alstroemeriaceae. Botanischesky Zhurnal 79: 1-8.

Neuendorf M. 1977. Pardiniae, a new section of Bomarea (Alstroemeriaceae). Botanical Notiser 130: 55-60.

Punt W, Hoen PP, Blackmore S, Nilsson S, Thomas A. 2007. Glossary of pollen and spore terminology. Review of Palaeobotany and Palynology 143: 1-81.

Rojas S, Gutiérrez S. 2001. Atlas palinológico de las plantas visitadas por Colibríes en el sff Galeras. Bogotá, Universidad Nacional de Colombia.

Rudall PJ, Stobart KL, Hong WP, et al. 2000. Consider the Lilies: Systematics of Liliales. In: Wilson KL, Morrison DA. (eds.) Monocots: Systematics and evolution. Melbourne, CSIRO. p. 347-358.

Sanso AM, Xifreda CC. 1995. El genero Bomarea (Alstroemeriaceae) en Argentina. Darwiniana 33: 315-336.

Sanso AM, Xifreda CC. 2001. Generic delimitation between Alstroemeria and Bomarea (Alstroemeriaceae). Annals of Botany 88: 1057-1069.

Sarwar AKM Golam, Hoshino Y, Araki H. 2010. Pollen morphology and infrageneric classification of Alstroemeria L. (Alstroemeriaceae). Grana 49: 227-242.

Schulze W. 1978. Beitragezur Taxonomie der Liliifioren III. Alstroemeriaceae. Wissenschaftliche Zeitschrift der Friedrich-Schiller-Universitat Jena/Thüringen. Mathematisch-naturwissenschaftliche Reihe 27: 79-85.

Thiers B. 2007. Index Herbariorum: A global directory of public herbaria and associated staff. New York Botanical Garden's Virtual Herbarium. http://sweetgum.nybg.org/ih/. 27 Jan. 2014.

Wodehouse RP. 1935. Pollen grains. Their structure, identification and significance in science and medicine. New York, McGraw Hill. 